\title{
Modelling the effects of climate and land cover change on groundwater recharge in south-west Western Australia
}

\author{
W. Dawes ${ }^{1}$, R. Ali ${ }^{1}$, S. Varma ${ }^{2}$, I. Emelyanova ${ }^{1}$, G. Hodgson ${ }^{1}$, and D. McFarlane ${ }^{1}$ \\ ${ }^{1}$ CSIRO Land and Water, Floreat, Western Australia \\ ${ }^{2}$ CSIRO Earth Science and Resource Engineering, Kensington, Western Australia
}

Correspondence to: W. Dawes (warrick.dawes@csiro.au)

Received: 17 April 2012 - Published in Hydrol. Earth Syst. Sci. Discuss.: 10 May 2012

Revised: 10 July 2012 - Accepted: 22 July 2012 - Published: 14 August 2012

\begin{abstract}
The groundwater resource contained within the sandy aquifers of the Swan Coastal Plain, south-west Western Australia, provides approximately 60 percent of the drinking water for the metropolitan population of Perth. Rainfall decline over the past three decades coupled with increasing water demand from a growing population has resulted in falling dam storage and groundwater levels. Projected future changes in climate across south-west Western Australia consistently show a decline in annual rainfall of between 5 and 15 percent. There is expected to be a reduction of diffuse recharge across the Swan Coastal Plain. This study aims to quantify the change in groundwater recharge in response to a range of future climate and land cover patterns across south-west Western Australia.

Modelling the impact on the groundwater resource of potential climate change was achieved with a dynamically linked unsaturated/saturated groundwater model. A vertical flux manager was used in the unsaturated zone to estimate groundwater recharge using a variety of simple and complex models based on climate, land cover type (e.g. native trees, plantation, cropping, urban, wetland), soil type, and taking into account the groundwater depth.

In the area centred on the city of Perth, Western Australia, the patterns of recharge change and groundwater level change are not consistent spatially, or consistently downward. In areas with land-use change, recharge rates have increased. Where rainfall has declined sufficiently, recharge rates are decreasing, and where compensating factors combine, there is little change to recharge. In the southwestern part of the study area, the patterns of groundwater recharge are dictated primarily by soil, geology and land cover. In the sand-dominated areas, there is little response to future
\end{abstract}

climate change, because groundwater levels are shallow and much rainfall is rejected recharge. Where the combination of native vegetation and clayey surface soils restricts possible infiltration, recharge rates are very sensitive to reductions in rainfall. In the northern part of the study area, both climate and land cover strongly influence recharge rates. Recharge under native vegetation is minimal and is relatively higher where grazing and pasture systems have been introduced after clearing of native vegetation. In some areas, the recharge values can be reduced to almost zero, even under dryland agriculture, if the future climate becomes very dry.

\section{Introduction}

Modelling the effect of potential climate change on plant growth and various components of a point or catchment water balance is widespread. Results are not consistent across the literature as the impact of global weather pattern change is not uniform in either direction or magnitude across the globe (Green et al., 2007). Eckhardt and Ulbrich (2003) used the SWAT-G model in the Dill Catchment in south-east Germany and found that mean groundwater recharge and stream flow could decrease by up to 50 percent, with negative effects on water quality, groundwater withdrawals and the generation of hydroelectric power. Conversely, Ficklin et al. (2009), using the SWAT model in the highly agricultural San Joaquin River catchment, found that increases in stream flow of up to 36 percent could be generated due to the interactions between shifts in crop growing times, irrigation demands, $\mathrm{CO}_{2}$, temperature and rainfall changes. Under an extreme scenario where atmospheric $\mathrm{CO}_{2}$ increased to $970 \mathrm{ppm}$, mean 
temperature increased by $+6.4{ }^{\circ} \mathrm{C}$ and rainfall decreased by 20 percent annually, stream flow increased by 5.7 percent. Legesse et al. (2003) used the PRMS model and found that, in a tropical catchment in Ethiopia, a decrease in rainfall of 10 percent led to a reduction in stream flow of 30 percent, while an increase in temperature of $1.5^{\circ} \mathrm{C}$ reduced stream flow by 15 percent.

In Australia, there are many potential impacts of climate change, summarised by Preston and Jones (2006). In the specific case of south-west Western Australia, they include coastal erosion, inundation of residential and commercial areas, decreased quality of food and fibre production, and reduced water availability for domestic and industrial uses. Commercial milk production, horticulture and vegetables, and timber plantations are all at risk of reduced viability from a changed climate in the region. As groundwater is the primary source of domestic drinking water, reduction in recharge to coastal source aquifers is a serious immediate threat that may be exacerbated by a growing future population and dependence on seawater desalination (Department of Water, 2009).

It has been recently shown through modelling that the most important factor influencing annual recharge is annual rainfall (McCallum et al., 2010). However, as other climatic parameters such as rainfall seasonality, rainfall intensity, air temperature, humidity and the concentration of atmospheric $\mathrm{CO}_{2}$ also exert an influence, there are enough exceptions to the simplistic rule of more rainfall equals more recharge to make local studies critically important (Rosenberg et al., 1999; Doll, 2009; Vivoni et al., 2009; Crosbie et al., 2010).

In November 2006, CSIRO was commissioned to undertake an assessment of sustainable yields of surface and groundwater systems within the $1 \mathrm{M} \mathrm{km}^{2}$ Murray-Darling Basin in southeastern Australia. The project provided a rigorous and detailed basin-scale assessment of the anticipated impacts of climate change, catchment development and increasing groundwater extraction on the availability and use of water resources (CSIRO, 2008). In March 2008, the Council of Australian Governments agreed to expand the CSIRO assessments of sustainable yield to cover northern Australia (CSIRO, 2009b), the state of Tasmania (Post et al., 2009), and the south-west of Western Australia (CSIRO, 2009a).

Across Australia, there was found to be considerable variation in the magnitude and direction of potential climate change in terms of rainfall, temperature, potential evaporation and vapour pressure. Modelled future climate change did not always result in a drying climate, and a decrease in rainfall did not always lead to a decrease in recharge (Crosbie et al., 2009, 2010). It is therefore vital that modelling studies are undertaken locally that assess the specific combination of climatic, land cover and human activity changes present. The geographic area of interest is the fresh groundwater resources of the Perth Basin from Geraldton in the north, down the west coast of Western Australia, and east to Albany (Fig. 1). It covers approximately $62500 \mathrm{~km}^{2}$ and contains 1.9 million

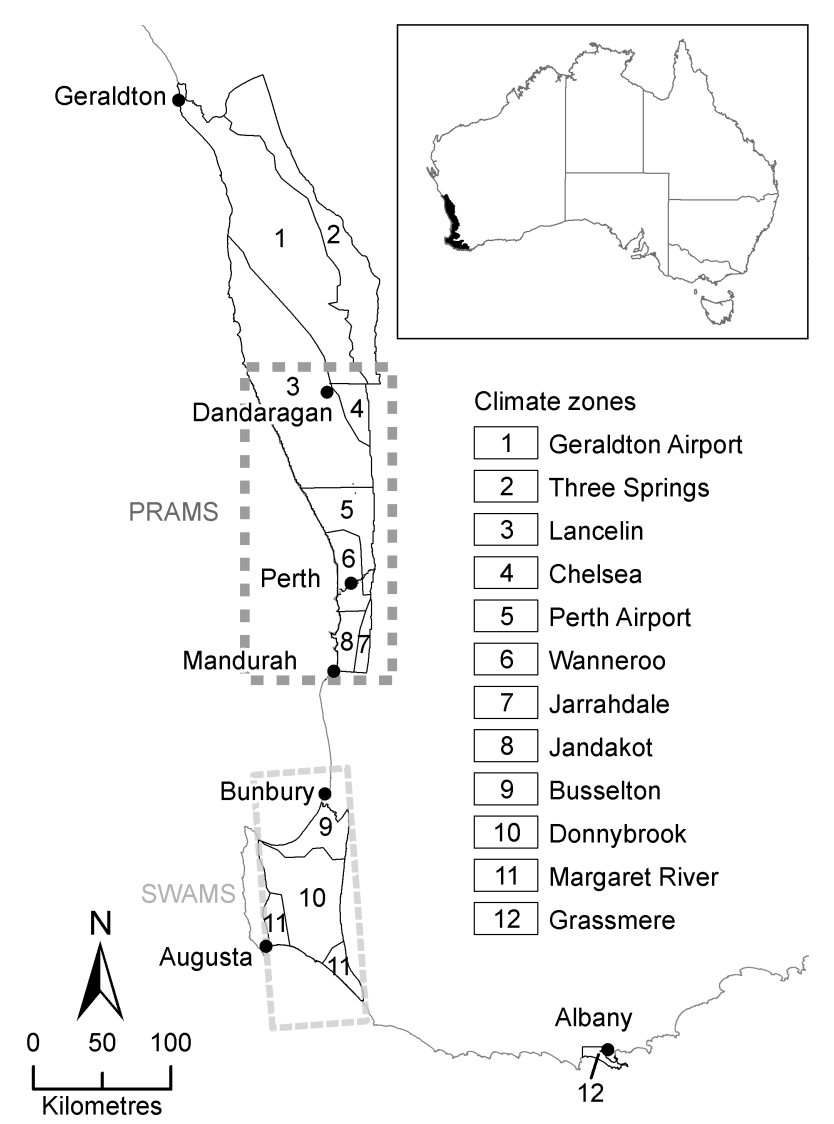

Fig. 1. Location map showing groundwater model regions and climate zones in the south-west of Western Australia.

people, with groundwater being the major water source for all human purposes, including more than 60 percent of drinking water. The Perth Basin comprises the flat sandy Swan and Scott Coastal Plains, and the more elevated and clayey Blackwood and Dandaragan Plateaux.

Several previous studies of recharge alone (Crosbie et al., 2010; $\mathrm{Ng}$ et al., 2010) and recharge to a groundwater model (e.g. Eckhardt and Ulbrich, 2003; Scibek and Allen, 2006) modelled recharge independently of groundwater, as free vertical drainage from an unsaturated soil column. Any underlying groundwater table was either not considered, or assumed to be deep enough to not influence the bottom of the model soil column. This work reports on the results of modelling diffuse recharge across the south-west of Western Australia. In the central and southern Perth Basin, a dynamically linked unsaturated/saturated model was used to model linked recharge and groundwater processes, while, in the more arid northern Perth Basin and the much smaller Albany area, only vertical unsaturated recharge to a fixed water table was modelled. A range of future climate changes from GCMs was used along with known and estimated land cover changes, while increasing groundwater extraction to the allocation limit was modelled with a single climate scenario. 


\section{Methods}

\subsection{Model description}

The model used in this work is MODFLOW-96 (McDonald and Harbaugh, 1996). MODFLOW is a standard two- and three-dimensional groundwater modelling program using a block-centred finite-difference approach. It is a modular program so that individual model processes can be turned on or off easily, and new processes introduced without modifying existing code. In this implementation, the evaporation module has been replaced with a vertical flux manager (VFM), and the recharge module is used to model diffuse extraction by hundreds of small unlicensed bores with unknown locations. In the areas reported here, the surface drainage system acts almost exclusively to drain groundwater, so all water courses were represented by the DRAIN package in MODFLOW. In the south-west corner of Western Australia, some areas become inundated in winter due to excess rainfall and stream flow from the higher elevation plateaus, and this extra available water was estimated externally by local-scale modelling and included as additional recharge input (Aquaterra, 2006).

The VFM calculates the net recharge or evaporation demand dynamically, using a selection of models dependent on land cover type and groundwater depth, run at a daily time step and then accumulated and applied to MODFLOW running on a monthly time step. The VFM uses three input surfaces: soil type, land cover type, and climate zone. For each unique combination of soil, land cover and climate, the VFM selects and runs an appropriate model for a series of groundwater depths. The net recharge or discharge flux is estimated in each model cell by interpolation using the local MODFLOW groundwater depth. Using this method reduced the number of recharge estimates from one per grid cell, e.g. approximately 40000 for the Perth regional aquifer, to one per response combination, e.g. $<700$ for Perth regional aquifer, while maintaining a dynamically linked system. Detailed descriptions of the VFM and model coding are given by Silberstein et al. (2002) and Barr et al. (2003).

The linked model was used where an existing MODFLOW model was available and could be suitably modified (South West Aquifer Modelling System, SWAMS), or where the linked model had already been set up and calibrated (Perth Regional Aquifer Modelling System, PRAMS). In two areas this was not possible, northern Perth Basin (NPB) and Albany area (AA), so net recharge or discharge flux was estimated directly with WAVES (Zhang and Dawes, 1998). WAVES (Water, Atmosphere, Vegetation, and Energy Simulation) is a daily time step one-dimensional water and energy balance model that simulates saturated and unsaturated flow through a soil column, to a water table or draining lower boundary, including the uptake of water by plant roots and the interactions with climatic forces. It is a physically based model that uses the Richards equation for vertical moisture flow and redistribution (Short et al., 1995), the PenmanMonteith combination equation for determining evaporative demand (Monteith, 1981), and an integrated rate method for modelling vegetation dynamics in response to light, temperature, water availability and concentration of atmospheric $\mathrm{CO}_{2}$ (Hatton et al., 1992; Wu et al., 1994). WAVES is one of the models used by the VFM for dynamically integrated modelling with MODFLOW-96.

\subsubsection{VFM input data}

The VFM requires three input layers to run any one of the candidate recharge models: soil type, land cover, and climate zone. A soil description is required for the WAVES modelling either within the VFM, or in stand-alone mode. The soil is conceptualised as a series of distinct layers of variable thickness, each with unique unsaturated hydraulic properties and response. The ASRIS (Australian Soil Resource Information System) soil database (Johnston et al., 2003) has been used both to classify major soil groups, and to specify some of the parameters required for an unsaturated hydraulic model. The large soil groups were sampled from GIS shapefiles to the MODFLOW grid used in PRAMS and SWAMS, and assigned a unique integer key that identified their description and properties for the VFM. Existing soil units, hydraulic models and parameters for PRAMS (Canci, 2004) and SWAMS (Sun, 2005) allocated during previous calibration runs were used without modification.

Where WAVES was used in a stand-alone mode in NPB and AA, the site information from ASRIS in the local area was recovered and analysed for a generic description of the soil profiles. Soil hydraulic parameters were then assigned to each soil layer based on representative values from the literature (Dawes et al., 2004). The deepest soil layer was extended uniformly downward to accommodate any desired depth to groundwater.

Land cover was determined across the study areas from Landsat 5 Thematic Mapper data, and a series of layers of known land cover combined sequentially. Data were available every two years from 1988 to 2002, and annually from 2003 to 2008. Initially, a normalised difference vegetation index (NDVI) is calculated for the remotely sensed image and native vegetation identified and classified according to inferred leaf area index (LAI). Known pine plantations are then masked in and classified by density based on LAI. Next, commercial and industrial areas are included using existing data for PRAMS and a national map of population centres (Geoscience Australia, 1998). Summer wet areas were identified by an NDVI threshold from mapped irrigation areas, and finally known water bodies were masked in. Any unclassified pixels were assumed to be dryland agriculture. More details of the methods and data sources used are available in Allen (2003), Canci (2004), Hodgson et al. (2005), Silberstein et al. (2004), Furby et al. (2008), CSIRO (2009a) and Ali et al. (2010). 
Each modelled area was divided into climate zones. Within each climate zone, each computational cell receives the same atmospheric inputs, supplied by a local meteorological station. Climate was supplied to the VFM as daily values of the quantities required to run any one of the vertical models. These data were maximum and minimum daytime temperature, average vapour pressure deficit, rainfall depth, fraction of the day that rain fell, total incident shortwave solar radiation, and pan evaporation depth. As WAVES is a candidate model of the VFM, no additional datasets were needed to run WAVES in the areas not covered by a linked MODFLOW model. SILO point-patched climate data (Jeffrey et al., 2001) were used for individual stations that described each climate zone.

\subsubsection{Groundwater model areas}

The existing linked PRAMS model covers an area of approximately $10000 \mathrm{~km}^{2}$, from Dandaragan in the north to Mandurah in the south, and from the western coastline to the Darling Fault in the east (Fig. 1). The model domain is $217 \mathrm{~km}$ long north-south, and between 20 and $107 \mathrm{~km}$ wide east-west. The region has three major aquifers, the Superficial, Leederville and Yarragadee, with a series of aquitards and minor aquifers of varying extent. The vertical profile is represented by 13 layers in MODFLOW, on a uniform grid $500 \mathrm{~m} \times 500 \mathrm{~m}$ aligned exactly north-south. The region is dominated by deep relatively uniform sand and gravel soil profiles with high hydraulic conductivity and low water holding capacity including the Bassendean, Spearwood, Quindalup and Mesozoic units. There are also small areas of Guildford Formation associated with the eastern edge of the model area and drainage lines that contain heavy clays. This model has been extensively calibrated and tested, and used for predicting water levels under different pumping regimes in some areas (Cymod, 2004; DOW, 2009).

The SWAMS model covers an area of approximately $6800 \mathrm{~km}^{2}$, from Bunbury in the north to Augusta in the south, and from the Dunsborough Fault in the west to the Darling Fault in the east (Fig. 1). It uses a variable mesh MODFLOW grid with cells ranging from $250 \mathrm{~m} \times 250 \mathrm{~m}$ to $1000 \mathrm{~m} \times 1000 \mathrm{~m}$, rotated 4.5 degrees anti-clockwise from north. This model contains the same major aquifers as PRAMS represented in eight layers. Although sand dune systems similar to those in PRAMS lie at the northern and southern boundaries of the SWAMS area, the central Blackwood Plateau area has clay-rich surface soils with low conductivity, and is an outcrop of the regional aquitard. Present also are outcropping areas of the deepest regional aquifer, with associated soils of high conductivity providing direct recharge. The linking with VFM and calibration of the model is described in Cymod (2009).

The NPB and AA do not have a VFM linked MODFLOW model; these were modelled using WAVES as a stand-alone product. The NPB covers an area from Dandaragan, at the northern edge of the PRAMS region, north of Geraldton, bounded by the natural coastline and Darling Fault. It has similar aquifers to PRAMS, including the LeedervilleParmelia and Yarragadee, but has complex faulting that makes them locally discontinuous. The area has low rainfall and low population, which leads to groundwater usage that is around 40 percent of the total amount available for licensing. Texture contrast soils are common in the basin with sandy and loamy top soils over clayey lower layers. Water tables are generally not close to the surface, being $10 \mathrm{~m}$ or deeper away from coastal dunes. In keeping with the PRAMS and SWAMS modelling, the leaf area index (LAI) and rooting distribution of the cover were fixed, along with the groundwater depth. The cover types are bare ground with no vegetation cover, perennial grass with an LAI of 1.0 and rooting depth of $1 \mathrm{~m}$ over a $10 \mathrm{~m}$ water table, and trees with an LAI of 0.5 and rooting depth of $5 \mathrm{~m}$ over a $10 \mathrm{~m}$ water table. At the Three Springs site with 15 percent less rainfall, the tree LAI was reduced to 0.33 .

The AA is a $212 \mathrm{~km}^{2}$ groundwater management unit $420 \mathrm{~km}$ south-east of the city of Perth on the south coast, at the edge of the geological Bremer Basin. The aquifer of interest here is in dune terrain over Tamala limestone up to $190 \mathrm{~m}$ thick, overlying layers of clay and siltstone aquitard and minor aquifers down to a granite basement. The city of Albany is a regional population centre, and the area's groundwater resource is currently licensed for 120 percent of its allocation limit of $4.2 \mathrm{GL} \mathrm{yr}^{-1}$. In the local sand dunes. there is a groundwater mound approximately $13 \mathrm{~m}$ above sea level that drains radially, and this is the location of the main bore fields. WAVES modelling in AA was conducted in the same manner as for NPB. Soil profiles were extracted from ASRIS and used to construct a generic soil profile for the coastal dunes. The same set of land covers was used, but, due to the high annual rainfall, the LAI of grass was increased to 2.0 to represent low but dense dune scrub, and the LAI of trees to 1.5 for native trees in a national forest.

\subsubsection{Climate scenarios}

The climatic variation imposed on the model regions is outlined in Tables 1, 2 and 3. These tables list the annual average rainfall, average daytime temperature, and average incoming solar radiation for each climate station and scenario used, and the percentage change from historical records. The baseline climate from the historical record 1975-2007 is considered the most reliable in terms of the collection of meteorological and groundwater data across the region, and representative of recent climate in the south-west following a discrete climate shift in the late 1960s and early 1970s (IOCI, 2006; Baines and Folland, 2007; Frederiksen and Frederiksen, 2007). The recent climate is from actual record for the period 1997-2007 which is a dry period used by the WA government for future water supply planning (Water Corporation, 2005). 
Table 1. Average annual rainfall (mm) for stations in study area, and deviation from historical record. Historical climate is from 1975-2007; recent climate is from 1997-2007; dry climate is from a future simulation derived from INMCM $+1.3^{\circ}$; median climate is from a future simulation derived from MIROC $+1.0^{\circ}$; wet climate is from a future simulation derived from GFDL $+1.3^{\circ}$.

\begin{tabular}{|c|c|c|c|c|c|c|c|c|c|}
\hline Rainfall (mm) & Historical & Recent & $\begin{array}{l}\text { Percent } \\
\text { change }\end{array}$ & Wet & $\begin{array}{l}\text { Percent } \\
\text { change }\end{array}$ & Median & $\begin{array}{l}\text { Percent } \\
\text { change }\end{array}$ & Dry & $\begin{array}{l}\text { Percent } \\
\text { change }\end{array}$ \\
\hline \multicolumn{10}{|l|}{ Northern Perth Basin } \\
\hline Geraldton Airport & 422.0 & 391.6 & -7.2 & 468.5 & 11.1 & 393.2 & -6.8 & 357.3 & -15.3 \\
\hline Three Springs & 361.0 & 355.0 & -1.8 & 399.5 & 10.5 & 332.1 & -8.1 & 274.0 & -24.2 \\
\hline \multicolumn{10}{|l|}{ Central Perth Basin } \\
\hline Chelsea & 464.5 & 465.8 & 0.3 & 502.2 & 8.1 & 450.1 & -3.1 & 407.9 & -12.2 \\
\hline Lancelin & 601.6 & 555.0 & -7.7 & 613.6 & 2.0 & 561.5 & -6.7 & 496.5 & -17.5 \\
\hline Perth Airport & 724.6 & 684.1 & -5.6 & 799.4 & 10.3 & 738.3 & 1.9 & 656.9 & -9.3 \\
\hline Wanneroo & 729.4 & 718.7 & -1.5 & 742.0 & 1.7 & 694.6 & -4.8 & 614.2 & -15.8 \\
\hline Jarrahdale & 1052.1 & 993.5 & -5.6 & 1130.6 & 7.5 & 1047.1 & -0.5 & 952.5 & -9.5 \\
\hline Jandakot & 840.2 & 785.0 & -6.6 & 851.7 & 1.4 & 784.3 & -6.7 & 714.4 & -15.0 \\
\hline \multicolumn{10}{|l|}{ Southern Perth Basin } \\
\hline Busselton & 744.5 & 708.6 & -4.8 & 751.5 & 1.0 & 687.7 & -7.6 & 628.3 & -15.6 \\
\hline Donnybrook & 903.8 & 895.2 & -1.0 & 888.6 & -1.7 & 813.6 & -10.0 & 745.7 & -17.5 \\
\hline Margaret River & 1046.1 & 986.0 & -5.7 & 1064.4 & 1.7 & 973.9 & -6.9 & 890.9 & -14.8 \\
\hline \multicolumn{10}{|l|}{ Albany area } \\
\hline Grassmere & 917.6 & 886.6 & -3.4 & 881.6 & -3.9 & 823.5 & -10.2 & 778.2 & -15.2 \\
\hline
\end{tabular}

Table 2. Average daytime temperature $\left({ }^{\circ} \mathrm{C}\right)$ for stations in study area, and deviation from historical record. Historical climate is from $1975-$ 2007; recent climate from is 1997-2007; dry climate is from a future simulation derived from INMCM $+1.3^{\circ}$; median climate is from a future simulation derived from MIROC $+1.0^{\circ}$; wet climate is from future simulation derived from GFDL $+1.3^{\circ}$.

\begin{tabular}{lccccccccc}
\hline Temperature $\left({ }^{\circ} \mathrm{C}\right)$ & Historical & Recent & $\begin{array}{c}\text { Percent } \\
\text { change }\end{array}$ & Wet & $\begin{array}{c}\text { Percent } \\
\text { change }\end{array}$ & Median & $\begin{array}{c}\text { Percent } \\
\text { change }\end{array}$ & $\begin{array}{c}\text { Dry } \\
\text { Percent } \\
\text { change }\end{array}$ \\
\hline $\begin{array}{l}\text { Northern Perth Basin } \\
\text { Geraldton Airport }\end{array}$ & 19.8 & 19.9 & 0.4 & 20.8 & 4.9 & 20.7 & 4.2 & 20.5 & 3.1 \\
Three Springs & 19.9 & 20.1 & 1.0 & 21.6 & 8.4 & 20.7 & 4.2 & 21.3 & 6.9 \\
\hline Central Perth Basin & & & & & & & & & \\
Chelsea & 18.9 & 18.9 & 0.3 & 20.1 & 6.4 & 19.7 & 4.2 & 20.0 & 5.8 \\
Lancelin & 18.8 & 18.9 & 0.6 & 20.0 & 6.3 & 19.5 & 3.6 & 19.9 & 5.8 \\
Perth Airport & 18.5 & 18.6 & 0.5 & 19.8 & 6.8 & 19.3 & 4.1 & 19.7 & 6.3 \\
Wanneroo & 18.5 & 18.5 & 0.2 & 19.7 & 6.7 & 19.2 & 4.0 & 19.6 & 6.2 \\
Jarrahdale & 16.8 & 16.9 & 0.4 & 18.1 & 7.4 & 17.6 & 4.4 & 17.8 & 5.4 \\
Jandakot & 18.1 & 17.7 & -2.5 & 19.2 & 6.0 & 18.7 & 3.2 & 18.9 & 4.2 \\
\hline Southern Perth Basin & & & & & & & & & \\
Busselton & 17.1 & 16.9 & -0.9 & 18.3 & 7.3 & 17.7 & 3.7 & 18.0 & 5.3 \\
Donnybrook & 16.7 & 16.8 & 0.4 & 17.9 & 7.4 & 17.3 & 3.7 & 17.6 & 5.5 \\
Margaret River & 16.6 & 16.4 & -0.8 & 17.8 & 7.5 & 17.3 & 4.2 & 17.5 & 5.5 \\
\hline Albany area & & & & & & & &
\end{tabular}

The future climate scenarios are derived from historical records by modifying individual values, such as temperature and rainfall, according to the statistical properties of climates generated by GCMs under 40 specific "storylines" (Charles et al., 2010). Each storyline varies the projected future global emissions of carbon dioxide, methane, nitrous oxide and sulphate aerosols resulting in different levels of global warming. Seasonal adjustments per degree of global warming for each climatic variable are generated by fitting lines through the simulated values for each GCM within individual computational cells. Daily downscaling is obtained by applying these rate constants to each climate variable considering the 
Table 3. Average daily solar radiation $\left(\mathrm{MJ} \mathrm{m}^{-2} \mathrm{~d}^{-1}\right)$ for stations in study area, and deviation from historical record. Historical climate is from 1975-2007; recent climate is from 1997-2007; dry climate is from a future simulation derived from INMCM $+1.3^{\circ}$; median climate is from a future simulation derived from MIROC $+1.0^{\circ}$; wet climate is from a future simulation derived from GFDL $+1.3^{\circ}$.

\begin{tabular}{|c|c|c|c|c|c|c|c|c|c|}
\hline Radiation $\left(\mathrm{MJ} \mathrm{m}^{-2} \mathrm{~d}^{-1}\right)$ & Historical & Recent & $\begin{array}{l}\text { Percent } \\
\text { change }\end{array}$ & Wet & $\begin{array}{l}\text { Percent } \\
\text { change }\end{array}$ & Median & $\begin{array}{l}\text { Percent } \\
\text { change }\end{array}$ & Dry & $\begin{array}{l}\text { Percent } \\
\text { change }\end{array}$ \\
\hline \multicolumn{10}{|l|}{ Northern Perth Basin } \\
\hline Geraldton Airport & 20.2 & 20.4 & 0.5 & 20.2 & -0.1 & 20.5 & 1.2 & 20.4 & 0.6 \\
\hline Three Springs & 19.8 & 19.9 & 0.4 & 19.5 & -1.4 & 20.0 & 1.2 & 19.9 & 0.7 \\
\hline \multicolumn{10}{|l|}{ Central Perth Basin } \\
\hline Chelsea & 19.3 & 19.5 & 1.1 & 19.2 & -0.3 & 19.6 & 1.5 & 19.5 & 1.2 \\
\hline Lancelin & 19.0 & 19.2 & 0.9 & 18.9 & -0.3 & 19.3 & 1.6 & 19.2 & 1.2 \\
\hline Perth Airport & 18.9 & 19.0 & 0.4 & 18.8 & -0.5 & 19.2 & 1.5 & 19.1 & 1.0 \\
\hline Wanneroo & 18.9 & 19.0 & 0.6 & 18.9 & -0.4 & 19.2 & 1.6 & 19.1 & 1.2 \\
\hline Jarrahdale & 18.4 & 18.5 & 0.5 & 18.3 & -0.5 & 18.7 & 1.5 & 18.6 & 1.1 \\
\hline Jandakot & 18.8 & 18.8 & 0.3 & 18.7 & -0.4 & 19.1 & 1.5 & 19.0 & 1.1 \\
\hline \multicolumn{10}{|l|}{ Southern Perth Basin } \\
\hline Busselton & 17.2 & 17.3 & 0.4 & 17.1 & -0.6 & 17.5 & 1.4 & 17.4 & 0.9 \\
\hline Donnybrook & 17.4 & 17.4 & -0.4 & 17.3 & -0.6 & 17.7 & 1.4 & 17.6 & 0.9 \\
\hline Margaret River & 16.7 & 17.0 & 1.6 & 16.6 & -0.6 & 16.8 & 0.7 & 16.9 & 0.9 \\
\hline \multicolumn{10}{|l|}{ Albany area } \\
\hline Grassmere & 16.2 & 16.3 & 0.7 & 16.1 & -0.1 & 16.5 & 1.8 & 16.3 & 0.5 \\
\hline
\end{tabular}

global temperature change. The climate downscaling method is described in detail by Chiew et al. $(2008,2009)$ and Crosbie et al. (2011).

The climatic sequences and statistics derived from GCM output are discussed by Charles et al. (2010), and were produced on a $0.05^{\circ} \times 0.05^{\circ}$ grid over continental Australia and Tasmania. Data from the nearest grid cell to an existing climate station were used for future scenarios. The future climate data were selected from $15 \mathrm{GCMs}$, three global warming scenarios and daily modelling output from the Intergovernmental Panel on Climate Change Fourth Assessment (IPCC, 2007; CSIRO and BOM, 2008; Chiew et al., 2008). WAVES was run using each of the possible variants of GCM and degree of warming scenario, assuming no surface vegetation and a fixed deep water table, and the results ranked by total accession to the water table. GCMs considered unreliable in terms of reproducing Southern Hemisphere weather phenomena and historic rainfall patterns over south-west Western Australia were discarded (Charles et al., 2007, 2010), and the choice of dry (second driest), median and wet (second wettest) future climate selected from those remaining. It was considered important to use a single GCM for each future scenario, rather than just the driest or wettest GCM at each climate station, to preserve regional-scale climate patterns.

The wet future scenario modifies the historical climate with adjustments to temperature, rainfall, humidity and radiation generated by the GFDL GCM (Delworth et al., 2006) where average global warming was $+1.3^{\circ} \mathrm{C}$. Median future uses adjustments from the MIROC GCM (K-1 Model Developers, 2004) where average global warming was $+1.0^{\circ} \mathrm{C}$, and dry future uses adjustments from the INMCM GCM (Diansky and Volodin, 2002) where average global warming was $+1.3^{\circ} \mathrm{C}$.

It should be noted that, although the average global warming in a particular scenario was $+1.0^{\circ} \mathrm{C}$, for example, the actual modelled change at any particular location across the globe may be more or less than that value. Changes in rainfall do not change uniformly, on either an annual or seasonal basis, and, while most stations might show an increase or decrease, in rainfall, others may experience the opposite. This is apparent in recent and all future climate scenarios relative to historical values.

In future climate runs, the land cover patterns and bore extraction amounts were assumed to be unchanging, and the same as the conditions present in 2007. This allows for the effects of the climate signal alone to be examined. The exception is in the PRAMS domain where legislated removal of pine plantations over the next $25 \mathrm{yr}$ was included and shows the strength of land use change relative to climate change. A further future run was developed that allowed for probable change in urban expansion and tree plantations up to 2030 , and increased bore extraction to full licensed volumes from the start of each simulation. This run used the median climate and is denoted as the development scenario. 


\subsection{Results}

\subsubsection{Recharge in central Perth Basin (Linked Model PRAMS)}

The annual average recharge contribution of each climate zone of PRAMS is presented in Table 4, with a map of the modelled average recharge in Fig. 2. The Lancelin climate zone represents nearly half of the model domain but provides just over one-third of the average recharge. This is a lower rainfall zone with about 10 percent less annual rainfall than the weighted average of PRAMS, but the highly conductive soils in this zone result in 24 percent of rainfall becoming recharge. This value is a repeated pattern in PRAMS with Chelsea, Lancelin, Perth Airport and Jandakot climate zones all having recharge of 23-27 percent of annual rainfall under Scenario A, although rainfall varies from 464 to $840 \mathrm{~mm}$. The two exceptions are Wanneroo and Jarrahdale. In the Wanneroo climate zone, there is significant land use change, mainly the legislated removal of pine plantations under which it is estimated there is close to zero recharge (Sharma and Pionke, 1984; DOW, 2009). In this zone, 41 percent of rainfall becomes modelled recharge due to a combination of the removal of pines, large areas of market gardens that have extensive sprinkler irrigation, and the presence of urban areas. The phenomenon when recharge increases due to land-use change effects are greater than rainfall decline due to climate change has been reported by Favreau et al. (2009) in Niger, Africa, and occurs again in this study in the NPB. In the Jarrahdale climate zone, there are the largest areas of high clay content, low conductivity soil types and deep-rooted perennial vegetation. In this climate zone, 13 percent of rainfall becomes recharge despite the average rainfall of $1052 \mathrm{~mm}$ under the historical climate.

The highest absolute rates of recharge occur in urban and industrial areas around the city of Perth. In these areas, runoff from roads, roofs and other hard surfaces is directed into the sandy superficial aquifer. Recharge in these locations may exceed 70 percent of rainfall (Sharma et al., 1991, 1995), and it is expected that this situation will continue. Areas of high net discharge are also visible in Fig. 2. These generally coincide with wetlands and groundwater-fed surface features, along with groundwater discharge areas that occur at the boundary between the Darling Scarp and Swan Coastal Plain.

Of note is the change in recharge between median and development. In the latter case, the most significant difference, and often only difference, is in licensed bore extraction. In areas where pumping was below licence limits and was increased to the maximum permissible, more rainfall became recharge as there is a large soil buffer created by declining water levels. This effect is evident in Lancelin, Jarrahdale and Jandakot climate zones. It is also clear from the percentage changes that future climatic effects on recharge are neither consistent in direction nor magnitude.

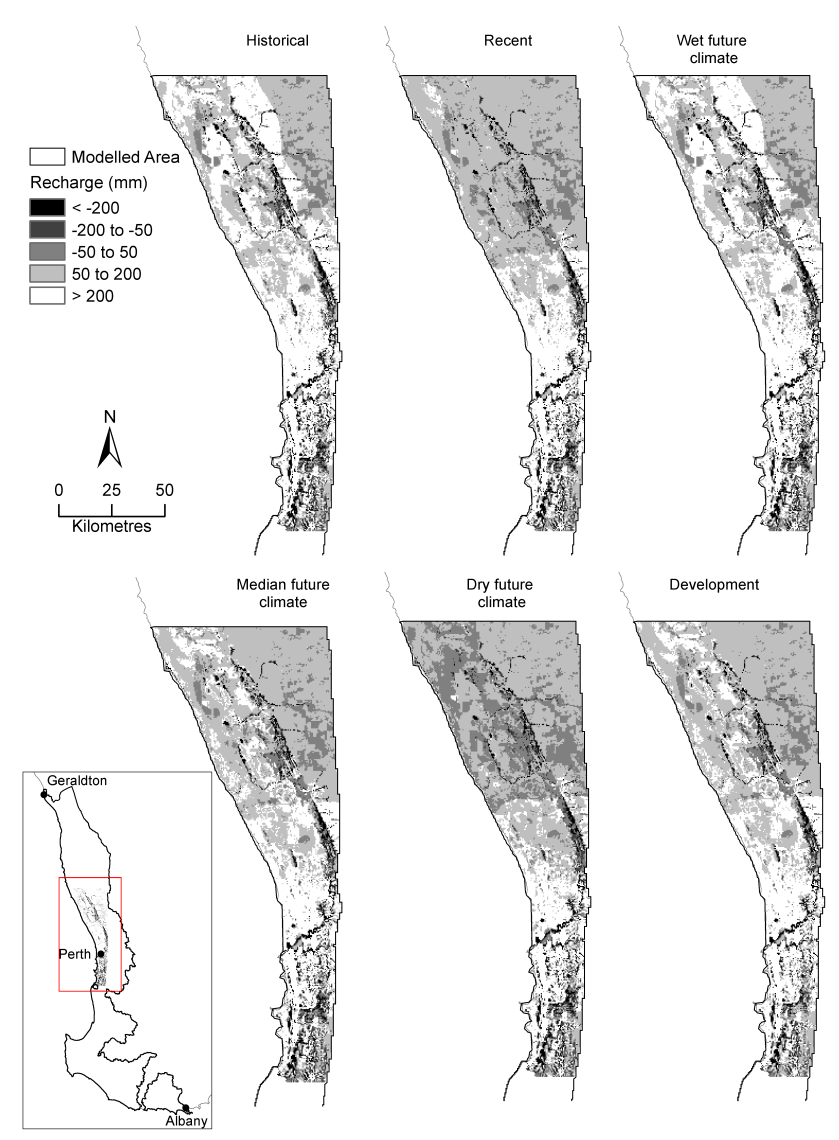

Fig. 2. Annual average recharge ( $\mathrm{mm}$ ) in the PRAMS model domain for the period 2008-2030. Scenario A is historical 1975-2007, B is historical 1997-2007, Cdry is historical 1984-2006 modified by IN$\mathrm{MCM}+1.3^{\circ} \mathrm{C}$, Cmid is historical $1984-2006$ modified by MIROC $+1.0^{\circ} \mathrm{C}$, Cwet is historical 1984-2006 modified by GFDL $+1.3^{\circ} \mathrm{C}$.

\subsubsection{Recharge in southern Perth Basin (Linked Model SWAMS)}

The average recharge contributions of each climate zone of SWAMS under all simulated future scenarios are presented in Table 4, with a map of the modelled average recharge in Fig. 3. The SWAMS area has higher average annual rainfall than the PRAMS area, but it is expected that rainfall will also drop by a larger amount in the south-west than in the Perth region. SWAMS has less recharge overall than PRAMS, and this is mainly due to the large areas in the region with low conductivity surface soils and deep- rooted native vegetation away from the coastal dune systems.

There are few areas in SWAMS with large positive modelled recharge values. These do include some of the southern Scott Coastal Plain areas, and the intake area for the outcropping Yarragadee Aquifer. Both areas have highly transmissive sandy soils and capacity within the aquifer for recharge to enter. Along the northern and western edges of the Blackwood Plateau, there are also smaller areas where large amounts of recharge can occur. 
Table 4. Average recharge $\left(\mathrm{mm} \mathrm{yr}^{-1}\right)$ simulated with linked MODFLOW models. Contribution and total recharge shown for each PRAMS and SWAMS climate zone using current and future climates, and percentage departure from modelled values of historical record. Recharge value is rounded off for presentation purposes.

\begin{tabular}{|c|c|c|c|c|c|c|c|c|c|c|c|c|}
\hline $\begin{array}{l}\text { Recharge } \\
\left(\mathrm{mm} \mathrm{yr}^{-1}\right)\end{array}$ & $\begin{array}{r}\text { Percent } \\
\text { area }\end{array}$ & Historical & Recent & $\begin{array}{l}\text { Percent } \\
\text { change }\end{array}$ & Wet & $\begin{array}{l}\text { Percent } \\
\text { change }\end{array}$ & Median & $\begin{array}{l}\text { Percent } \\
\text { change }\end{array}$ & Dry & $\begin{array}{l}\text { Percent } \\
\text { change }\end{array}$ & Devel & $\begin{array}{l}\text { Percent } \\
\text { change }\end{array}$ \\
\hline \multicolumn{13}{|c|}{ Central Perth Basin } \\
\hline Chelsea & 15 & 19 & 16 & -12 & 20 & 10 & 15 & -20 & 12 & -34 & 15 & -20 \\
\hline Lancelin & 45 & 65 & 47 & -28 & 63 & -3 & 49 & -24 & 35 & -46 & 51 & -21 \\
\hline Perth A'port & 13 & 37 & 35 & -7 & 35 & -6 & 33 & -13 & 27 & -28 & 33 & -12 \\
\hline Wanneroo & 12 & 20 & 17 & -18 & 23 & 11 & 19 & -5 & 14 & -31 & 19 & -5 \\
\hline Jarrahdale & 9 & 19 & 17 & -12 & 16 & -18 & 14 & -25 & 15 & -24 & 16 & -17 \\
\hline Jandakot & 6 & 8 & 8 & -9 & 8 & -1 & 8 & -8 & 7 & -20 & 10 & 19 \\
\hline Total & 100 & 169 & 139 & -18 & 165 & -2 & 139 & -18 & 109 & -35 & 144 & -14 \\
\hline \multicolumn{13}{|c|}{ Southern Perth Basin } \\
\hline Busselton & 23 & 15 & 12 & -18 & 15 & 1 & 12 & -17 & 10 & -31 & 15 & 1 \\
\hline Donnybrook & 59 & 28 & 25 & -9 & 21 & -24 & 16 & -44 & 11 & -59 & 16 & -41 \\
\hline Margaret R. & 18 & 24 & 17 & -30 & 23 & -2 & 17 & -27 & 12 & -50 & 18 & -25 \\
\hline Total & 100 & 67 & 54 & -19 & 59 & -11 & 45 & -32 & 33 & -50 & 49 & -26 \\
\hline
\end{tabular}

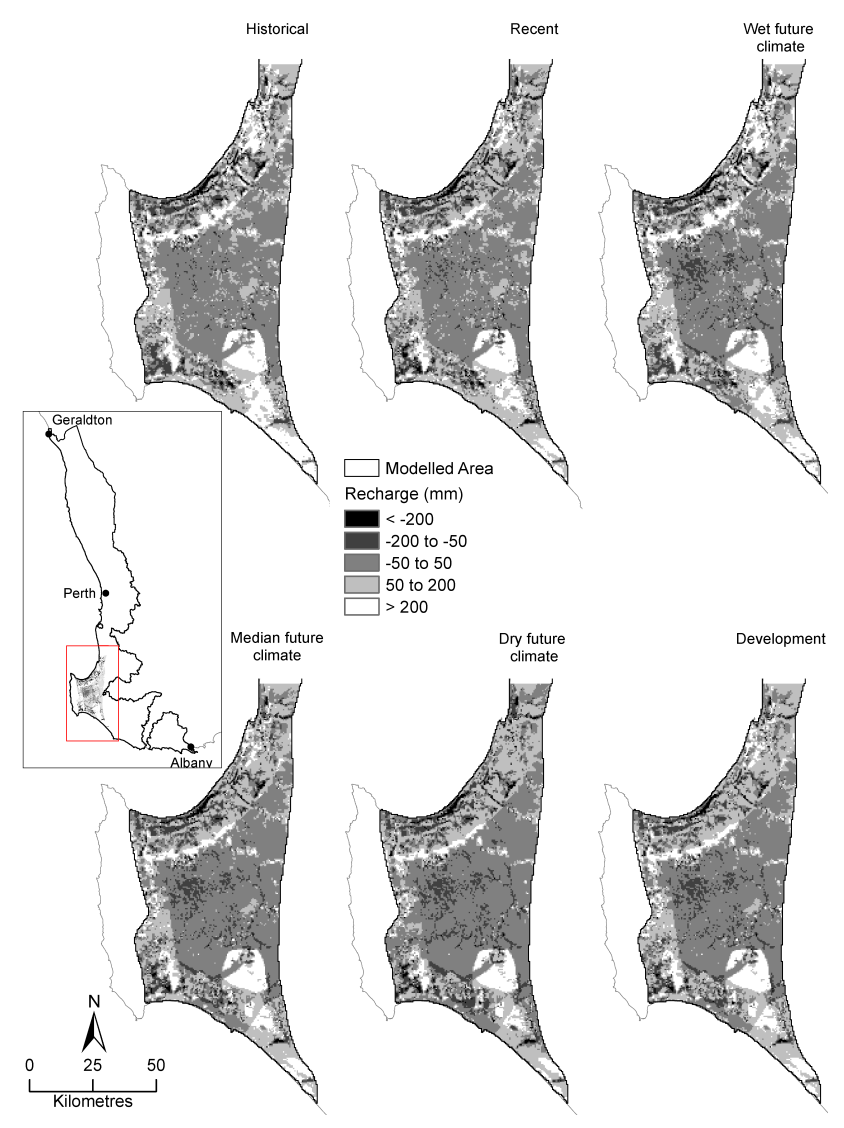

Fig. 3. Annual average recharge $(\mathrm{mm})$ in the SWAMS model domain for the period 2008-2030. Scenario A is historical 1975-2007, B is historical 1997-2007, Cdry is historical 1984-2006 modified by INMCM $+1.3^{\circ} \mathrm{C}$, Cmid is historical 1984-2006 modified by MIROC $+1.0^{\circ} \mathrm{C}$, Cwet is historical 1984-2006 modified by GFDL $+1.3^{\circ} \mathrm{C}$
The contribution to overall recharge from the Donnybrook climate zone, in which much of the low conductivity soil and regolith appears, is affected greatest by simulated future climates. Here the contribution drops by up to 59 percent under dry as rainfall declines by 18 percent. With drier future climate sequences, the recharge across much of the Blackwood Plateau is close to zero, and with large areas of native vegetation it may become a net discharge area. It is of interest that the much smaller Margaret River climate zone makes the largest contribution to the regions recharge under all future climate scenarios. Busselton with the smallest contribution is the least affected by future changes, but with the greatest capacity for future development will allow rainfall that was previously rejected due to saturated surface conditions, to become recharge under development. For the overall SWAMS region, the simulated decline in average recharge is up to 50 percent.

\subsubsection{Recharge in northern Perth Basin (WAVES Model)}

In NPB the WAVES model was run for various land covers on the dominant soil type within the Geraldton Airport and Three Springs climate zones. The recharge predictions for the future climate scenarios are summarised in Table 5. The entries of negative recharge are an artefact of running the WAVES model with a fixed groundwater lower boundary condition in keeping with PRAMS and SWAMS. However, the result is consistent with the work of Bekele et al. (2006) who did not encounter water tables below most areas of native vegetation in the region. The single positive recharge value under trees occurs in the Geraldton Airport climate zone with wet future climate. In this case, the rainfall increases by 11 percent or $46 \mathrm{~mm}$, while solar radiation decreases slightly and average temperature 
Table 5. Average recharge $\left(\mathrm{mm} \mathrm{yr}^{-1}\right)$ simulated with WAVES model. Recharge rates shown for northern Perth Basin and Albany area climate zones using current and future climates, and percentage departure from modelled values of historical record. Recharge value is rounded off for presentation purposes.

\begin{tabular}{|c|c|c|c|c|c|c|c|c|c|c|}
\hline Recharge $\left(\mathrm{mm} \mathrm{yr}^{-1}\right)$ & Cover & Historical & Recent & $\begin{array}{l}\text { Percent } \\
\text { change }\end{array}$ & Wet & $\begin{array}{l}\text { Percent } \\
\text { change }\end{array}$ & Median & $\begin{array}{l}\text { Percent } \\
\text { change }\end{array}$ & Dry & $\begin{array}{l}\text { Percent } \\
\text { change }\end{array}$ \\
\hline \multicolumn{11}{|l|}{ Northern Perth Basin } \\
\hline \multirow[t]{3}{*}{ Geraldton Airport } & None & 226 & 201 & -11 & 253 & 12 & 205 & -9 & 167 & -26 \\
\hline & Grass & 46 & 33 & -29 & 63 & 39 & 37 & -20 & 18 & -61 \\
\hline & Trees & -4 & -4 & 0 & 9 & 111 & -4 & 0 & -4 & 0 \\
\hline \multirow[t]{3}{*}{ Three Springs } & None & 82 & 75 & -9 & 94 & 14 & 69 & -16 & 42 & -48 \\
\hline & Grass & 9 & 7 & -26 & 11 & 22 & 5 & -44 & 0 & -99 \\
\hline & Trees & -8 & -8 & 0 & -8 & 0 & -8 & 0 & -9 & -12 \\
\hline \multicolumn{11}{|l|}{ Albany area } \\
\hline \multirow[t]{3}{*}{ Grassmere } & None & 593 & 561 & -5 & 550 & -7 & 505 & -15 & 469 & -21 \\
\hline & Grass & 254 & 246 & -3 & 226 & -11 & 201 & -21 & 177 & -31 \\
\hline & Trees & 215 & 191 & -11 & 174 & -19 & 140 & -35 & 109 & -49 \\
\hline
\end{tabular}

increases by 4.9 percent or 1 degree. At the Three Springs site, the future climates with reduced rainfall lead to a modelled drop in recharge of up to 99 percent under perennial grass cover. Bekele et al. (2006) found in these zones that aquifers where native vegetation had been replaced by grazed farming systems had steadily rising water levels. They estimated the recharge rate over the past three decades was 20 to $50 \mathrm{~mm} \mathrm{yr}^{-1}$. These rates encompass the WAVES recharge estimates for perennial grass cover.

\subsubsection{Recharge in Albany area (WAVES Model)}

Recharge rates under the selected land uses and future climate scenarios are reported in Table 5. This is a small area, and only a single climate zone was used over the sub-area of interest. Under all recent and future climate scenarios, there is a decrease in both rainfall and recharge in AA. A decrease in future rainfall of 15 percent under dry future results in a reduction in recharge of 21 to 49 percent across the land uses. A groundwater modelling study of the area used both chloride profiles and steady-state groundwater modelling to estimate recharge over the sand dunes (URS and Dames and Moore, 2000). They reported an average recharge rate of $220 \mathrm{~mm} \mathrm{yr}^{-1}$, which accords well with the grass and tree recharge estimates from WAVES under historical climate scenario.

\subsection{Discussion}

\subsubsection{Recharge changes under climate scenarios}

In general in the areas modelled, a decline in rainfall has led to a decline in recharge, and vice versa, in the absence of other human activities. Two areas of note where human activity has impacted on recharge, contrary to the climatic signal, are Wanneroo in PRAMS and Busselton in SWAMS.
In the Wanneroo climate zone, there is a significant area of pine plantation that is legislated for removal over the next two decades. In previous field and modelling studies, the recharge under plantation pines has been estimated at close to zero, while under less dense native scrub, it may be more than $100 \mathrm{~mm} \mathrm{yr}^{-1}$ (DOW, 2009; Silberstein et al., 2005). The modelling predictions suggest that, as rainfall increases under wet scenario by 1.7 percent, recharge increases by 11 percent; this is a greater change in both absolute and percentage terms. Under the median scenario, rainfall is projected to reduce by 4.8 percent and recharge by 5 percent, which is a smaller change in absolute recharge. Had future land use included expansion, rather than reduction, of the area of pine plantation we might expect the effect of recharge reduction due to rainfall decline to be amplified.

In the Busselton climate zone, human activities that increase the soil water deficit act to increase net recharge. Under the median scenario, rainfall reduces by 7.6 percent which leads to a reduction in recharge of 17 percent; in absolute terms, the rainfall reduces by $56 \mathrm{~mm} \mathrm{yr}^{-1}$ while recharge drops by $9 \mathrm{~mm} \mathrm{yr}^{-1}$. The development scenario includes an increase in bore extraction from the current licensed $32 \mathrm{GL} \mathrm{yr}^{-1}$ up to the allocation limit of $44 \mathrm{GL} \mathrm{yr}^{-1}$. This acts to lower groundwater levels and allow more rainfall to infiltrate and become recharge. In this case the rainfall reduction of $56 \mathrm{~mm} \mathrm{yr}^{-1}$ plus additional pumping increases net recharge by 1 percent, or $3 \mathrm{~mm} \mathrm{yr}^{-1}$, as previously excess rainfall over shallow water tables becomes recharge.

A feature of the SWAMS model is that many coastal areas become inundated in winter with both excess rainfall and stream flow from rivers running through the Blackwood Plateau ponding on the land surface. This water is a source of recharge if the soil buffer is enlarged through greater pumping, or if local rainfall decreases. However, reductions in stream flow as a result of future climate drying, not modelled 


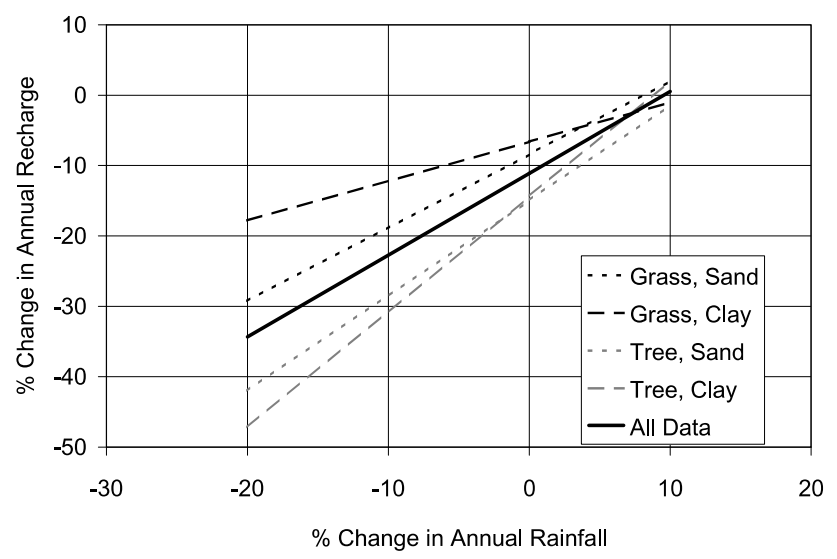

Fig. 4. Percentage change in rainfall versus percentage change in recharge to water table in PRAMS model.

in this exercise, would have a further negative impact on water available for recharge.

There is no integration of model predictions for the NPB, as this was simply an exercise in estimating point recharge. Classification of land cover type in the NPB areas estimates that 29 percent is low density native vegetation, 68 percent is dryland agriculture although it is most likely grazing, with 3 percent in other categories. Using these percentages and the recharge values in Table 5, under historical climate, the average recharge would be $37 \mathrm{~mm} \mathrm{yr}^{-1}$ in the Geraldton Airport climate zone, and $6 \mathrm{~mm} \mathrm{yr}^{-1}$ across Three Springs. In both zones of the NPB, the aggregated recharge decreases by 25 percent under recent climate. Changes under the other scenarios are closely linked with changes in the recharge under grass type cover as this is the largest proportion of land area. Of most concern is the potential reduction to near-zero recharge under dry scenario in the Three Springs zone. If this were to occur, then any groundwater resource would be lost for future exploitation.

WAVES recharge estimates for AA indicate uniformly decreasing amounts into the future. All vegetation covers using recent climate compared to all future scenarios show a progressive reduction in rainfall and a corresponding reduction in recharge. The recharge under trees has been 11 percent less under recent climate than the historical, and even under the wettest estimated future climate this is modelled to reduce by 19 percent below historical levels. The absolute reduction in rainfall in the dry scenario is $140 \mathrm{~mm} \mathrm{yr}^{-1}$, which leads to a reduction in recharge of $107 \mathrm{~mm} \mathrm{yr}^{-1}$, or 49 percent. This pattern is repeated under the other cover types used, with modelled recharge under dune grass reducing by up to $77 \mathrm{~mm} \mathrm{yr}^{-1}$, or a 31 percent reduction.

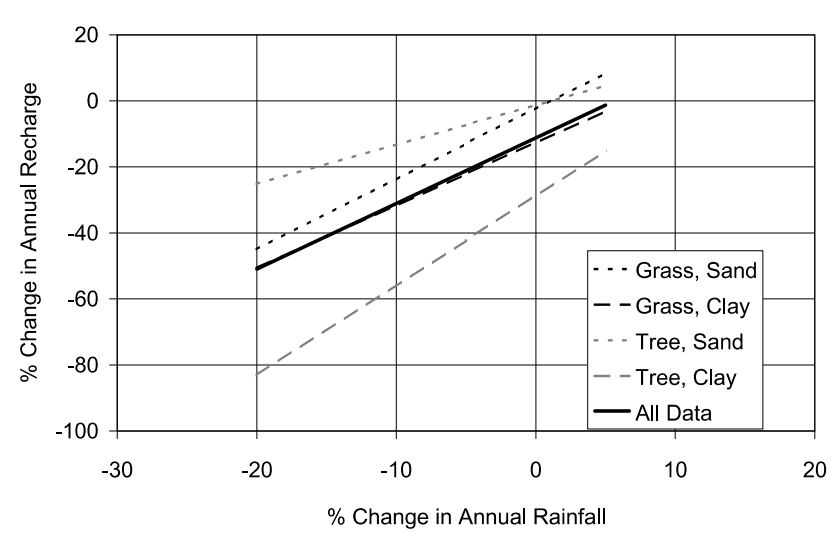

Fig. 5. Percentage change in rainfall versus percentage change in recharge to water table in SWAMS model.

\subsubsection{Recharge sensitivity to rainfall, soil type and land cover}

The modelled net recharge data from PRAMS, SWAMS, NPB and Albany were assembled for four major combinations of soil and land cover type: predominantly sand and clay soils, with grass and medium native vegetation. For the simplified analysis of NPB and Albany area, the data have been grouped as there is direct control over water table depth, vegetation and climate. For PRAMS and SWAMS, the data have been extracted as long-term averages for all cells in the model domain with the required land cover and soil type in each climate zone.

Figure 4 shows the least-squares lines of best fit for percentage change in recharge as a result of changes in rainfall in the PRAMS model domain. The individual data points are not shown as there is considerable scatter: coefficient of correlation for the grass land cover is 0.33 , while it is 0.09 for trees and similar for the combined data. Individual graphs are available in the Supplement. The most notable feature is that all lines tend to converge between zero and $+10 \%$ change in rainfall leading to $-10 \%$ to no change in recharge. This is likely the result of increases in temperature and solar radiation leading to increases in evaporation and transpiration, along with changes in the number of rainy days. If this model result becomes a reality, then it points to a reduction in recharge even if rainfall does not decline further. The two lines for land cover over a sandy soil profile lie above the combined data, while the two lines for the clay soil profile are below. This suggests that the sandy soils in the area are less sensitive to climate change than the clay profiles. It is uniformly the case that a given percentage reduction in rainfall suggests an equal or greater reduction in recharge, as all slopes are between 1 and 2; the slope of the combined data is 1.2 .

Figure 5 shows the least-squares lines of best fit for percentage change in recharge as a result of changes in rainfall in the SWAMS model domain. Like the PRAMS result, the prediction for a sandy soil profile lies above the combined 


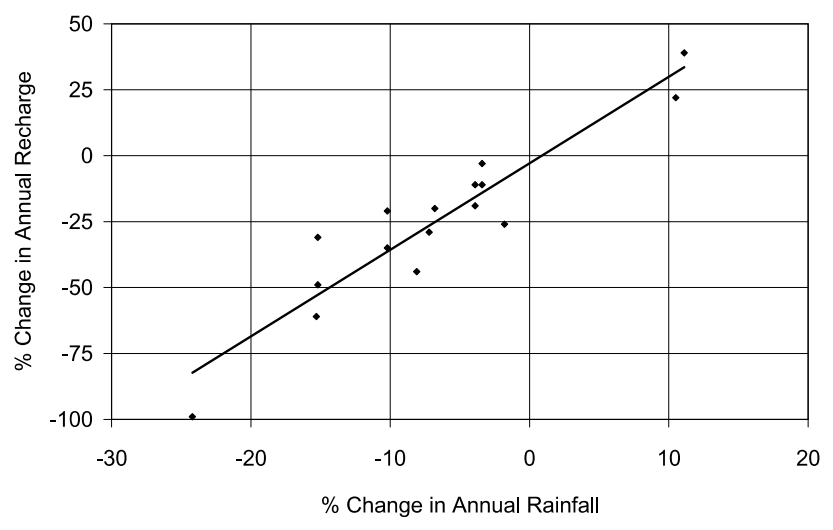

Fig. 6. Percentage change in rainfall versus percentage change in recharge to water table in NPB and Albany.

data line, while the clay predictions are at or below it. Unlike the PRAMS results, the sandy soil predictions both converge to no change in rainfall leading to no change in recharge. The area is dominated by lower conductivity clay soils however, and those results are both for a decrease in recharge even with existing rainfall amounts, and a slope between 2 and 3 (i.e. a unit percentage change in rainfall leads to a 2 to 3 unit percentage change in recharge). As with the PRAMS results, there is considerably more scatter for the tree cover type than for grass cover; see the Supplement for individual graphs of cover and soil type.

Figure 6 shows the combined predictions of NPB and Albany simulations using WAVES alone. Here the data points are shown, and there is a clear positive relationship between percentage change in rainfall and percentage change in recharge. Here the coefficient of correlation is 0.87 for the 16 data points. This line also passes nearly through the origin, implying no change in rainfall will lead to no change in recharge. The slope of the line is close to 3 , implying a $1 \%$ change in rainfall leads to a $3 \%$ change in recharge. These data cover a range of annual rainfall from 300 to $1000 \mathrm{~mm}$.

The consistent downward trend of predicted future rainfall in the south-west of Western Australia is repeated in similar rainfall regimes across the Southern Hemisphere. IPCC (2007) show that more than $90 \%$ of GCMs predict a reduction in rainfall of 10 to $25 \%$ over the next century, relative to 1980-1999, on the south-west coasts of South America, Africa and Australia in the band 30 to $40^{\circ} \mathrm{S}$ latitude. Hulme et al. (2001) confirms the historical observed reduction in rainfall in southern Africa, and projected future reductions in rainfall, with the largest changes in winter rainfall. With a winter dominant rainfall regime, such as in the south-west of Western Australia, reductions in winter rainfall cause the greatest changes to total rainfall. The sensitivity of recharge reduction is ultimately a result of land cover and soil physical properties at the specific location. In this study, recharge under shallow-rooted vegetation on highly conductive soils was the least sensitive to rainfall change, while deep-rooted trees and less conductive clay-rich soils were most sensitive.

\section{Conclusions}

Recharge was estimated for current and future climate regimes in south-west Western Australia using an unsaturated one-dimensional vertical model coupled to a saturated three-dimensional groundwater model. Where this was not possible, the unsaturated vertical model was used to estimate recharge to a suitably deep water table. In the central part of the Perth Basin, recharge changes are affected by both change in land cover and climate patterns. In the Dandaragan Plateau, recharge in cleared areas is greater now and into the future than under trees have been historically, so water levels that have been rising since the 1970s will continue to rise into the future. Recharge in the area around Wanneroo primarily responds to removal of pine plantations thus causing recharge to increase despite a reduction in rainfall into the future.

In areas where future pumping pressure results in an increase in bore abstraction, recharge can increase due to a greater soil buffer being created. This applies both to the central and southern Perth Basin models on soils that are primarily sand dunes or have sand-dominated soil profiles, such as Lancelin, Busselton and Margaret River climate zones. For areas with low conductivity surface soils, such as the Jarrahdale climate zone in the central region and Donnybrook climate zone in the south, recharge can decrease by up to 50 percent with a much smaller decrease in rainfall.

In areas where only a vertical unsaturated model was used, results were for a consistently large reduction in recharge with future drier climates. In the more arid north, recharge under grass cover could potentially reduce by between 60 and 99 percent, while it may increase under trees on coastal areas if average rainfall increases. Along the wet southern coast near Albany, modelled recharge reductions were 30 to 50 percent, which would be extremely serious as the area is already over-allocated for groundwater extraction.

Relative changes in recharge compared to rainfall indicate that sandy soils are less sensitive to projected climate changes than the same land cover on clay soils. In addition, deep-rooted native vegetation and tree cover types were more sensitive to climate change than grass cover types. The slope of the relationships is between 1 and 3 for all combinations of soil, cover and climate examined, indicating that, for a unit change in rainfall, there is a 1 to 3 -fold change in recharge. In the PRAMS area, the modelling indicates that recharge may decline even if total rainfall remains the same.

While this study is focussed on south-west Australia, the conclusions and recharge sensitivities are likely to be applicable to similar geographic regions in South America and southern Africa.

\section{Supplementary material related to this article is available online at: http://www.hydrol-earth-syst-sci.net/ 16/2709/2012/hess-16-2709-2012-supplement.zip.}


Acknowledgements. This work is part of the South-West Western Australia Sustainable Yields Project undertaken by CSIRO under the direction and funding of the Australian Government Department of the Environment, Water, Heritage and the Arts. Contributions were made by CSIRO Land and Water, Department of Water Western Australia, Water Corporation, Western Australia Department of Agriculture and Food, URS Australia P/L, CyMod Systems, Jim Davies and Associates, Resource Economics Unit, and Geographic Information Analysis.

Edited by: N. Basu

\section{References}

Ali, R., Emelyanova, I., Dawes, W., Hodgson, G., McFarlane, D. M., Varma, S. and Turner, J.: Groundwater methods used in the south-west Western Australia Sustainable Yields project, a report to the Australian Government from the CSIRO South-West Western Australia Sustainable Yields Project, CSIRO Water for a Healthy Country National Research Flagship, Australia, 117 pp., 2010.

Allen, A: Perth Groundwater Model Project. Historic Land Use Mapping Component. Project Outline, Methods and Outputs, Department of Land Administration, Technical Report for Water Corporation of Western Australia, 24 pp., 2003.

Aquaterra Consultants: Eastern Scott Coastal Plain local-scale groundwater and surface water model, report to Department of Water, Western Australia, 64 pp., 2006.

Baines, P. and Folland, C.: Evidence for a rapid global climate shift across the late 1960s, J. Climate, 20, 2721-2744, 2007.

Barr, A.D., Xu, C., and Silberstein, R. P.: Vertical Flux model for the Perth regional aquifer model system - draft description and user manual, CSIRO Consultancy Report to Water Corporation, Western Australia, 49 pp., 2003.

Bekele, E., Salama, R. B., and Commander, P. D.: Impact of changes in vegetation cover on groundwater recharge to a phreatic aquifer in Western Australia: assessment of several recharge estimation techniques, Aust. J. Earth Sci., 53, 905-917, 2006.

Canci, M.: Preparation of spatial data for the vertical flux model, Technical Report, Water Corporation of Western Australia, 25 pp., 2004.

Charles, S. P., Bari, M., Kitsios, A., and Bates, B. C.: Effect of GCM bias on downscaled precipitation and runoff predictions for the Serpentine catchment, Western Australia, Int. J. Climatol., 27, 1673-1690, doi:10.1002/joc.1508, 2007.

Charles, S. P., Silberstein, R. P., Teng, J., Fu, G., Hodgson, G., Gabrovsek, C., Crute, J., Chiew, F. H. S., Smith, I. N., Kirono, D. G. C., Bathols, J. M., Li, L-T., Yang, A., Donohue, R.J., Marvanek, S.P., McVicar, T.R., van Niel, T. G., and Cai, W.: Climate analyses for the South-West Western Australia, a report to the Australian Government from the CSIRO South-West Western Australia Sustainable Yields Project, CSIRO Water for a Healthy Country Flagship, Australia, 127 pp., 2010.

Chiew, F. H. S., Teng, J., Kirono, D. G. C., Frost, A. J., Bathols, J. M., Vaze, J., Viney, N. R., Young, W. J., Hennessy, K. J., and Cai, W. J.: Climate data for hydrologic scenario modelling across the Murray-Darling Basin, a report to the Australian Government from the CSIRO Murray-Darling Basin Sustainable Yields
Project, CSIRO Water for a Healthy Country Flagship, Australia, 98 pp., 2008.

Chiew, F. H. S., Teng, J., Vaze, J., Post, D. A., Perraud, J. M., Kirono, D. G. C., and Viney, N. R.: Estimating climate change impact on runoff across southeast Australia: Method, results, and implications of the modelling method, Water Resour. Res., 45, W10414, doi:10.1029/2008WR007338, 2009.

Crosbie, R. S., McCallum, J. L., and Harrington, G. A.: Diffuse groundwater recharge modelling across northern Australia, a report to the Australian Government from the CSIRO Northern Australia Sustainable Yields Project, CSIRO Water for a Healthy Country Flagship, Australia, 56 pp., 2009.

Crosbie, R. S., McCallum, J. L., Walker, G. R., and Chiew, F. H. S.: Modelling the climate change impact on groundwater recharge in the Murray-Darling Basin, Hydrogeol. J., 18, 1639-1656, 2010.

Crosbie, R. S., Dawes, W. R., Charles, S. P., Mpelasoka, F. S., Aryal, S., Barron, O., and Summerell, G. K.: Differences in future recharge estimates due to GCMs, downscaling methods and hydrological models, Geophys. Res. Lett., 38, L11406, doi:10.1029/2011GL047657, 2011.

CSIRO: Water availability in the Murray-Darling Basin, a report to the Australian Government from the CSIRO Murray-Darling Basin Sustainable Yields Project, CSIRO Water for a Healthy Country Flagship, Australia, 112 pp., 2008.

CSIRO: Groundwater yields in south-west Western Australia, a report to the Australian Government from the CSIRO South-West Western Australia Sustainable Yields Project, CSIRO Water for a Healthy Country Flagship, Australia, 2009a.

CSIRO: Water in Northern Australia, a report to the Australian Government from the CSIRO Northern Australia Sustainable Yields Project, Water for a Healthy Country National Research Flagship, Australia, 2009b.

CSIRO and Australian Bureau of Meteorology: Climate change in Australia, Technical Report, CSIRO, Australia, 148 pp., 2008.

Cymod Systems Pty Ltd: Calibration of the coupled Perth Regional Aquifer Model, PRAMS 3.0., report prepared for Water Corporation of Western Australia and Department of Water, Western Australia, 54 pp., 2004.

Cymod Systems Pty Ltd: Calibration of the South West Yarragadee Aquifer Model with the VFM, report prepared for CSIRO, Western Australia, 48 pp., 2009.

Dawes, W. R., Zhang, L., and Dyce, P.: WAVES v3.5 User Manual, CSIRO Land and Water, Canberra, 20 pp., 2004.

Delworth, T. L., Broccoli, A. J., Rosati, A., Stouffer, R. J., Balaji, V., Beesley, J. A., Cooke, W. F., Dixon, K. W., Dunne, J. P., Dunne, K. A., Durachta, J. W., Findell, K. L., Ginoux, P., Gnanadesikan, A., Gordon, C. T., Griffies, S., Gudgel, R., Harrison, M. J., Held, I., Hemler, R. S., Horowitz, L., Klein, S. A., Knutson, T. R., Kushner, P. J., Langenhorst, A. R., Lee, H. C., Lin, S.-J., Lu, J., Malyshev, S., Milly, P. C. D., Ramaswamy, V., Russell, J. L., Schwarzkopf, M. D., Shevliakova, E., Sirutis, J. J., Spelman, M. J., Stern, W. F., Winton, M., Wittenberg, A. T., Wyman, B., Zeng, F., and Zhang, R.: GFDL's CM2 Global Coupled Climate Models. Part I: Formulation and Simulation Characteristics, J. Climate, 19, 643-674, doi:10.1175/JCLI3629.1, 2006.

Department of Water: Perth-Peel regional water plan 2010-2030: responding to our drying climate, a report for the Government of Western Australia, Perth, 74 pp., available at: http://www.water. wa.gov.au/PublicationStore/first/90639.pdf, last access: Decem- 
ber 2009.

Diansky, N. A. and Volodin, E. M.: Simulation of present-day climate with a coupled atmosphere-ocean general circulation model, Izvestiya, Atmos. Ocean. Phys., 38, 732-747, 2002.

Doll, P.: Vulnerability to the impact of climate change on renewable groundwater resources: a global-scale assessment, Environ. Res. Lett., 4, 035006, doi:10.1088/1748-9326/4/3/035006, 2009.

DOW: Gnangara Sustainability Strategy. Managing land and groundwater for the future, Department of Water, Government of Western Australia, 2009.

Eckhardt, K. and Ulbrich, U.: Potential impacts of climate change on groundwater recharge and streamflow in a central European low mountain range, J. Hydrol., 284, 244-252, doi:10.1016/j.jhydrol.2003.08.005, 2003.

Favreau, G., Cappelaere, B., Massuel, S., Leblanc, M., Boucher, M., Boulain, N., and Leduc, C.: Land clearing, climate variability, and water resources increase in semiarid southwest Niger: a review, Water Resour. Res., 45, W00A16, doi:10.1029/2007WR006785, 2009.

Ficklin, D. L., Luo, Y., Luedeling, E., and Zhang, M.: Climate change sensitivity assessment of a highly agricultural watershed using SWAT, J. Hydrol., 374, 16-29, doi:10.1016/j.jhydrol.2009.05.016, 2009.

Frederiksen, J. and Frederiksen, C.: Interdecadal changes in Southern Hemisphere winter storm track modes, Tellus A, 59, 599617,2007

Furby, S., Zhu, M., Wu, X., and Wallace, J.: Vegetation extent and change 1988-2008. South West Agricultural Region of Western Australia, 2008 Update of the Land Monitor II Project \#1 - Vegetation Change, Technical Report, CSIRO Mathematics and Information Sciences, Perth, Western Australia, 2008.

Geoscience Australia: Coarse Cultural Topographic Datasets: population centres. ANZLIC ANZCW0703002389, Geoscience Australia, Australian Government, available at: http://www.ga.gov. au/meta/ANZCW0703002389.html, last access: February 2012, 1998.

Green, T. R., Taniguchi, M., and Kooi, H.: Potential impacts of climate change and human activity on subsurface water resources, Vadose Zone J., 6, 531-532, doi:10.2136/vzj2007.0098, 2007.

Hatton, T. J., Walker, J., Dawes, W. R., and Dunin, F. X.: Simulation of hydroecological responses to elevated $\mathrm{CO}_{2}$ at the catchment scale, Aust. J. Bot., 40, 679-696, 1992.

Hodgson, G., Higginson, S., Couple, K., and Silberstein, R. P.: Leaf Area Index mapping of native banksia woodland and development of a Landsat LAI calibration for the Gnangara Mound, CSIRO Land and Water Technical Report, Western Australia, 33 pp., 2005.

Hulme, M., Doherty, R., Ngara, T., New, M., and Lister, D.: African climate change: 1900-2100, Clim. Res., 17, 145-168, 2001.

IOCI: Indian Ocean Climate Initiative Stage 2: Report of Phase 2 Activity January 2005-June 2006, 40 pp., available at: www.ioci.org.au/publications/doc_download/ 34-ioci-second-phase-complete-report.html (last access: January 2007), 2006.

IPCC: Climate Change 2007: The physical science basis. Contributions of Working Group 1 to the Fourth Assessment Report of the Intergovernmental Panel of Climate Change, Cambridge University Press, Cambridge, UK, 2007.
Jeffrey, S. J., Carter, J. O., Moodie, K. B., and Beswick, A. R.: Using spatial interpolation to construct a comprehensive archive of Australian climate data, Environ. Modell. Softw., 16, 309-330, 2001.

Johnston, R. M., Barry, S. J., Bleys, E., Bui, E. N., Moran, C. J., Simon, D. A. P., Carlile, P., McKenzie, N. J., Henderson, B. L., Chapman, G., Imhoff, M., Maschmedt, D., Howe, D., Grose, C., Schoknecht, N., Powell, B., and Grundy, M.: ASRIS: the database, Aust. J. Soil Res., 41, 1021-1036, 2003.

K-1 Model Developers: K-1 coupled GCM (MIROC) description, in: K-1 Technical Report 1, Center for Climate System Research, edited by: Hasumi, H. and Emori, S., University of Tokyo, Tokyo, available at: http://www.ccsr.u-tokyo. ac.jp/kyosei/hasumi/MIROC/tech-repo.pdf (last access: September 2004), 2004.

Legesse, D., Vallet-Coulomb, C., and Gasse, F.: Hydrological response of a catchment to climate and land use changes in Tropical Africa: case study South Central Ethiopia, J. Hydrol., 271, 67-85, doi:10.1016/S0022-1694(03)00019-2, 2003.

McCallum, J. L., Crosbie, R. S., Walker, G. R., and Dawes, W. R.: Impacts of climate change on groundwater: A sensitivity analysis of recharge, Hydrogeol. J., 18, 1625-1638, 2010.

McDonald, M. and Harbaugh, A.: User's documentation for MODFLOW-96, an update to the US Geological Survey Modular finite difference Groundwater Flow Model, US Geological Survey, Open-File Report 96-485, 1996.

Monteith, J. L.: Evaporation and surface temperature, Q. J. Roy. Meteor. Soc., 107, 1-27, 1981.

Ng, G.-H. C., McLaughlin, D., Entekhabi, D., and Scanlon, B. R.: Probabilistic analysis of the effects of climate change on groundwater recharge, Water Resour. Res., 46, W07502, doi:10.1029/2009WR007904, 2010.

Post, D. A., Chiew, F. H. S., Teng, J., Vaze, J., Yang, A., Mpelasoka, F., Smith, I., Katzfey, J., Marston, F., Marvanek, S., Kirono, D., Nguyen, K., Kent, D., Donohue, R., Li, L., and McVicar, T.: Production of climate scenarios for Tasmania, a report to the Australian Government from the CSIRO Tasmania Sustainable Yields Project, CSIRO Water for a Healthy Country Flagship, Australia, 58 pp., 2009.

Preston, B. L. and Jones, R. N.: Climate change impacts on Australia and the benefits of early action to reduce global greenhouse gas emissions, a consultancy report for the Australian Business Roundtable on Climate Change, CSIRO, Canberra, 41 pp., 2006.

Rosenberg, N. J., Epstein, D. J., Wang, D., Vail, L., Srinivasan, R., and Arnold, J. G.: Possible impacts of global warming on the hydrology of the Ogallala Aquifer region, Clim. Change, 42, 677692, 1999.

Scibek, J. and Allen, D. M.: Modeled impacts of predicted climate change on recharge and groundwater levels, Water Resour. Res., 42, W11405, doi:10.1029/2005WR004742, 2006.

Sharma, M. and Pionke, H.: Estimating groundwater recharge from measurements of environmental tracers in the vadose zone, in: Proceedings of NWWA/US EPA Conference on characterisation and monitoring of the vadose (unsaturated) zone, Las Vegas, Nevada, August 1984, 799-819, 1984.

Sharma, M., Byrne, R., Herne, D., and Kin, P.: Impact of horticulture on water and nutrient fluxes to a sandy aquifer, CSIRO Division of Water Resources, Report 91/33, Perth, Western Australia, 105 pp., 1991. 
Sharma, M., Herne, D., Byrne, R., and Kin, P.: Leaching of nutrients beneath urban lawns to an unconfined sandy aquifer, CSIRO Division of Water Resources, Report 95/12, Perth, Western Australia, 111 pp., 1995.

Short, D. L., Dawes, W. R., and White, I.: The practicability of using Richards' equation for general purpose soil-water dynamics models, Environ. Int., 21, 723-730, 1995.

Silberstein, R. P., Barr, A. D., Hodgson, G., Pollock, D., Salama, R., and Hatton, T.: A vertical flux model for the Perth groundwater region. Phase 2 - development of the Vertical Flux Model (VFM) to manage the data flow and computation of recharge and groundwater discharge to the atmosphere, interim report to the Water Corporation, Western Australia, 55 pp., 2002.

Silberstein, R., Higginson, S., Hodgson, G., and Couple, K.: Leaf Area Index mapping and Landsat calibration of Pinus Pinaster plantations on the Gnangara Mound, Technical Report for Water Corporation of Western Australia, CSIRO Land and Water, Western Australia, 35 pp., 2004.

Silberstein, R., Hick, W., Walker, S., Higginson, S., Dawes, W., and Dumbrell, I.: Spatial and temporal water use of Pine plantations on Gnangara Mound, report to the Water Corporation and Gnangara Alliance, Western Australia, 32 pp., 2005.
Sun, H.: Construction, calibration and application of the Southwest Yarragadee Aquifer Model V2, Technical Report, Water Corporation of Western Australia, 40 pp., 2005.

URS, Dames and Moore: Albany Source Modelling Approach in Estimating Available Groundwater Resources, Report prepared for the Water Corporation, Western Australia, 60 pp., 2000.

Vivoni, E. R., Aragón, C. A., Malczynski, L., and Tidwell, V. C.: Semiarid watershed response in central New Mexico and its sensitivity to climate variability and change, Hydrol. Earth Syst. Sci., 13, 715-733, doi:10.5194/hess-13-715-2009, 2009.

Water Corporation: Integrated water supply scheme, security through diversity, 2005-2050: an overview, Water Corporation, Western Australia, 12 pp., 2005.

Wu, H., Rykiel Jr., E. J., Hatton, T. J., and Walker, J.: An integrated rate methodology (IRM) for multi-factor growth rate modelling, Ecol. Model., 73, 97-116, 1994.

Zhang, L. and Dawes, W. R.: WAVES - An integrated energy and water balance model, CSIRO Land and Water Technical Report No. 31/98, Canberra, 24 pp., 1998. 